УДК 619:616.995.132:636.598:612.1

(C) 2017

Сресько В. І., здобувач

(науковий керівник - доктор ветеринарних наук, професор В. О. Свстаф'єва)

Полтавська державна аграрна академія

\title{
ВПЛИВ КАПІЛЯРІЙ НА ГЕМАТОЛОГІЧНІ ПОКАЗНИКИ ІНВАЗОВАНИХ ГУСЕЙ
}

\section{Рецензент - кандидат ветеринарних наук О. С. Клименко}

У статті представлені результати проведених досліджень щзодо впливу капілярій різних видів: Capilaria obsignata i Capilaria anseris на гематологічні показники інвазованих гусей. Вперше на території Полтавської області доведено паразитування у гусей виду C. obsignata. 3'ясовано, щуо цей вид виявився менш патогенним, ніж C. anseris. Паразитування $у$ водоплавної птиці виду C. anseris призводило до значного зниження в їх крові вмісту гемоглобіну, кількості еритроцитів, достовірного підвищення кількості лейкоцитів, а також встановлювали зростання відсотку еозинофілів, псевдоеозинофілів та зниження лімфоцитів.

Ключові слова: Capilaria obsignata, Capilaria anseris, гуси, гематологічні показники, капіляріозна інвазія.

Постановка проблеми. Відомо, що птахівництво $€$ однією із найдинамічніших галузей тваринництва в Україні та в низці країн світу. Його розвиток сприяє швидкому нарощуванню різноманітних продуктів харчування і значному підйому економічного базису населення середнього й низького достатку в аграрному секторі. Важливим резервом збільшення виробництва м'яса в Україні є розвиток гусівництва, як традиційної галузі в нашій державі $[2,5]$.

Гельмінтози суттєво впливають на збереження, вирощування молодняку та продуктивність дорослої птиці, чим завдають птахівництву значних збитків. Так, у дорослої птиці знижується несучість та зменшується вгодованість, у молодняка гельмінти зумовлюють значне відставання у рості і розвитку, а за значної інтенсивності призводять до його загибелі від виснаження та інтоксикації продуктами метаболізму. Паразитичні черви сприяють проникненню в організм інфекційних та бактеріальних хвороб $[1,8]$.

Аналіз останніх досліджень і публікацій, у яких започатковано розв'язання проблеми. Весь комплекс патологічного впливу паразита на організм хазяїна залежить від багатьох чинників: його виду, вірулентності, чисельності, місця локалізації, біології і фізіологічного стану організму тварини. В даний час вчені вважають, що патогенез при гельмінтозах - це складний ком- плекс взаємопов'язаних та взаємообумовлених патологічних процесів і явищ, що виникають внаслідок патогенного впливу гельмінтів та відповідної реакції організму господаря $[3,4,6]$.

Зокрема, гельмінти чинять механічну дію на тканини організму тварини, а продукти їх метаболізму (секрети, гормони, екскременти гельмінтів) $є$ антигенами і сприяють розвитку запальних реакцій $[10,11]$.

Так, за даними Л. М. Соловйової (2005) [9], за гіменолепідідозної інвазії в крові водоплавної птиці знижується вміст гемоглобіну, кількість еритроцитів, вміст загального білка і альбумінів, розвивається лейкоцитоз, еозинофілія, лімфоцитоз, зростає відсоток глобулінових фракцій білка. Водночас зростає активність аланін- і аспартатамінотрансферази, лужної фосфатази, альфаамілази, що свідчить, на думку автора, про порушення функцій печінки, підшлункової залози та інших систем організму.

Також, I. А. Мухаметшин (2004) [7] експериментально встановив, що за гельмінтозної інвазії у курчат затримується їх ріст та розвиток, внаслідок чого знижується приріст живої маси молодняку (за 70 діб на 150 г). Водночас у м'ясі інвазованих курчат збільшується вміст загальної вологи на 7,53 \%, знижується вміст сухої речовини на $10,38 \%$, загального білка - на $1,22 \%$, жиру - на 8,6\%, а енергетична цінність м'яса зменшується на 77,4 кДж.

У зв'язку з цим метою роботи було визначення впливу капіляріозної інвазії на гематологічні показники інвазованих гусей.

У завдання досліджень входило встановити зміни у показниках крові гусей, інвазованих гельмінтами видів Capilaria obsignata і Capilaria anseris; 3'ясувати ступінь патогенності досліджуваних видів капілярій.

Матеріали і методи досліджень. Дослідження проводилися упродовж грудня 2016 року січня 2017 року на базі наукової лабораторії кафедри паразитології та ветеринарно-санітарної експертизи Полтавської державної аграрної академії. Експериментальні досліди виконували в умовах одноосібних селянських господарств 
Шишацького та Гадяцького районів Полтавської області.

3 метою визначення впливу різних видів капілярій на гематологічні показники інвазованих гусей були сформовані дві дослідні групи птиці віком 8-9 місяців (спонтанно інвазовані Capilaria obsignata та Capilaria anseris), а також дві контрольні (клінічно здорові гуси) по вісім голів у кожній.

Морфологічні показники вивчали за загальноприйнятими методами. Кількість еритроцитів i лейкоцитів підраховували у лічильній камері Горяєва. Лейкограму виводили підрахунком лейкоцитів у мазках крові, пофарбованих за методом Папенгейма. Вміст гемоглобіну визначали гемоглобінціанідним методом. Статистичну обробку результатів експериментальних досліджень проводили шляхом визначення середнього арифметичного (M), його похибки (m) та рівня вірогідності (p) 3 використанням таблиці t-критеріїв Стьюдента.

Результати досліджень. За результатами гельмінтологічних розтинів органів травлення гусей в умовах одноосібних селянських господарств Полтавської області вперше зареєстрова- ний збудник Capilaria obsignata, який паразитує у суходільної птиці. Також одночасно виявляли, характерний для гусей, вид капілярій Capilaria anseris.

За результатами гематологічних досліджень птиці, інвазованої різними видами капілярій встановлені значні відмінності у показниках (табл. 1, 2).

Згідно 3 даними таблиці 1 , у крові гусей, інвазованих гельмінтами Capilaria obsignata, відмічали незначні зміни, які характеризувалися зниженням кількості еритроцитів на 27,6\% $(2,1 \pm 0,3$ Т/л, $\mathrm{p}<0,05$ відносно контрольної групи

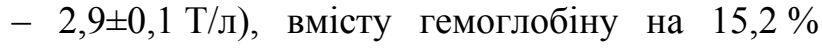
$(89,5 \pm 1,5$ г/л, $\mathbf{p}<0,05$ відносно контрольної групи - 105,5 5,6 г/л), збільшенням кількості лейкоцитів на 11,6\% $(27,4 \pm 0,9$ Г/л, $\mathbf{p}<0,05$ відносно контрольної групи - 31,0土0,9 Г/л). У лейкоформулі встановлювали збільшення відсотку еозинофілів на $22,9 \%(9,6 \pm 0,7 \%, \mathrm{p}<0,05$ відносно контроль-

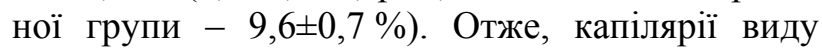
C. obsignata призводили до розвитку анемії, внаслідок крововиливів, які виникають на слизовій оболонці кишечника в разі механічного іiі пошкодження гельмінтами.

\section{1. Гематологічні показники гусей, інвазованих гельмінтами виду Capillaria obsignata, $n=8, M \pm m$}

\begin{tabular}{|l|c|c|c|}
\hline \multicolumn{1}{|c|}{ Показники } & $\begin{array}{c}\text { Клінічно здорові } \\
\text { гуси }\end{array}$ & $\begin{array}{c}\text { Гуси, інвазовані } \\
\text { капіляріями }\end{array}$ & $\begin{array}{c}\text { Референтні } \\
\text { коливання }\end{array}$ \\
\hline Еритроцити, Т/л & $2,9 \pm 0,1$ & $2,1 \pm 0,3^{*}$ & $2,5-3,5$ \\
\hline Гемоглобін, г/л & $105,5 \pm 5,6$ & $89,5 \pm 1,5^{*}$ & $90,0-135,0$ \\
\hline Лейкоцити, Г/л & $27,4 \pm 0,9$ & $31,0 \pm 0,9^{*}$ & $20,0-30,0$ \\
\hline \multicolumn{3}{|c|}{ Лейкограма, \% } \\
\hline Базофіли & $2,3 \pm 0,2$ & $2,1 \pm 0,1$ & $1,0-3,0$ \\
\hline Еозинофіли & $7,4 \pm 0,4$ & $9,6 \pm 0,7^{*}$ & $3,0-9,0$ \\
\hline Псевдоеозинофіли & $38,8 \pm 0,7$ & $38,1 \pm 0,9$ & $30,0-44,0$ \\
\hline Лімфоцити & $47,4 \pm 0,8$ & $46,3 \pm 0,8$ & $40,0-56,0$ \\
\hline Моноцити & $4,3 \pm 0,5$ & $3,9 \pm 0,6$ & $2,0-6,0$ \\
\hline
\end{tabular}

Примітка: * - p $<0,05$ - відносно показників клінічно здорової птиці.

\section{2. Гематологічні показники гусей, інвазованих гельмінтами виду Capillaria anseris, $n=8, M \pm m$}

\begin{tabular}{|l|c|c|c|}
\hline \multicolumn{1}{|c|}{ Показники } & $\begin{array}{c}\text { Клінічно здорові } \\
\text { гуси }\end{array}$ & $\begin{array}{c}\text { Гуси, інвазовані } \\
\text { капіляріями }\end{array}$ & $\begin{array}{c}\text { Референтні } \\
\text { коливання }\end{array}$ \\
\hline Еритроцити, Т/л & $3,4 \pm 0,2$ & $2,3 \pm 0,2^{* *}$ & $2,5-3,5$ \\
\hline Гемоглобін, г/л & $99,5 \pm 2,3$ & $88,1 \pm 2,1^{* *}$ & $90,0-135,0$ \\
\hline Лейкоцити, Г/л & $27,1 \pm 1,0$ & $31,1 \pm 0,7^{* *}$ & $20,0-30,0$ \\
\hline \multicolumn{3}{|c|}{ Лейкограма, \% } \\
\hline Базофіли & $2,3 \pm 0,2$ & $1,8 \pm 0,2$ & $1,0-3,0$ \\
\hline Еозинофіли & $7,0 \pm 0,3$ & $9,5 \pm 0,7^{* *}$ & $3,0-9,0$ \\
\hline Псевдоеозинофіли & $38,9 \pm 0,6$ & $41,3 \pm 0,9^{*}$ & $30,0-44,0$ \\
\hline Лімфоцити & $47,8 \pm 0,9$ & $44,3 \pm 0,8^{*}$ & $40,0-56,0$ \\
\hline Моноцити & $4,1 \pm 0,6$ & $3,3 \pm 0,4$ & $2,0-6,0$ \\
\hline
\end{tabular}

Примітка: ${ }^{*}-\mathrm{p}<0,05 ;{ }^{* *}-\mathrm{p}<0,01-$ відносно показників клінічно здорової птиці. 
Незначний лейкоцитоз та еозинофілія, які виникають у інвазованих гусей, $\epsilon$ характерною ознакою запальних явищ і алергізації організму продуктами життєдіяльності паразитів. Водночас в уражених гусей не виявляли будь-яких клінічних ознак хвороби.

У гусей, інвазованих C. anseris, виявляли більш значні зміни у їх гематологічних показниках порівняно із птицею ураженою C. obsignata (табл. 2). Так, у крові дослідних гусей виявляли значне зниження кількості еритроцитів на $32,4 \%$ $(2,3 \pm 0,2 \mathrm{~T} / л, \mathrm{p}<0,01)$ та вмісту гемоглобіну на $11,5 \%(88,1 \pm 2,1$ г/л, $\mathrm{p}<0,01)$ порівняно із показниками у клінічно здорових гусей $(3,4 \pm 0,2$ T/л та 99,5 $\pm 2,3$ г/л відповідно). Одночасно реєстрували зростання кількості лейкоцитів на $12,9 \%$ (31, $1 \pm 0,7$ Г/л, $\mathrm{p}<0,01$ відносно контрольної групи $-27,1 \pm 1,0$ Г/л), еозинофілів на $26,3 \%(9,5 \pm 0,7 \%$, $\mathrm{p}<0,01$ відносно контрольної групи $-7,0 \pm 0,3 \%$ ), псевдоеозинофілів на 5,8 \% $(41,3 \pm 0,9 \%, \mathrm{p}<0,05$

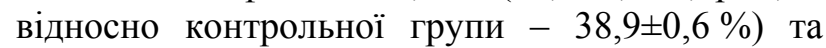
зниження кількості лімфоцитів на 7,3\% $(44,3 \pm 0,8 \%, \mathrm{p}<0,05$ відносно контрольної групи $-47,8 \pm 0,9 \%)$. Водночас у дослідної птиці клінічно відзначали схуднення та ознаки анемії. Отже, $C$. anseris викликає значне механічне пошко-

\section{БІБЛІОГРАФІЯ}

1. Богач М. В. Природно-вогніщеві гельмінтози водоплавної птиці в господарствах Одеської області / М. В. Богач // Ветеринарна медицина. 2010. - Вип. 94. - С. 268-269.

2. Вертійчук A. I. Шляхи подальшого розвитку птахівництва в Україні / А. І. Вертійчук // Ефективне птахівництво. - 2008. - №11 (47). - С. 3-5.

3. Даугалаева Э. Х. Особенности иммунитета при гельминтозах / Э. Х. Даугалаева // Ветеринария. - 1996. - №7. - С. 37-38.

4. Ионов М. П. Влияние амидостомозной инвазии на перевариваемость кормов и усваиваемость питательных веществ у гусей. - В кн. : «Борьба с инвазионными болезнями сельскохозяйственных животных» / М. П. Ионов. - Уфа, 1976. - C. 41-45.

5. Івко I. I. Шляхи підвищення ефективності вітчизняного гусівництва / I. І. Івко, О. В. Рябініна, О. В. Мельник // Ефективне птахівництво. - 2010. - №11 (71). - С. 33-40.

6. Крылов М. В. Инфекционные и инвазионные болезни водоплавающих птиц / М. В. Крылов, А. Б. Терюханов. - Л. : Колос, 1975. - C. 57-59. дження слизової оболонки стінки кишечника, крововиливи i, як наслідок, розвиток еритропенії та зниження вмісту гемоглобіну. Зростання кількості лейкоцитів вказує на розвиток запальних явищ, а зниження кількості лімфоцитів - на виникнення імунодефіциту внаслідок хронічного перебігу хвороби.

\section{Висновки:}

1. Проведеними гематологічними дослідженнями інвазованих гусей встановлено, що гельмінти виду C.anseris є більш патогенними, ніж C. obsignata.

2. Паразитування C. obsignata характеризувалася незначними змінами в крові хворих гусей 3 боку кількості еритроцитів, лейкоцитів, еозинофілів та вмісту гемоглобіну.

3. У крові гусей, інвазованих гельмінтами виду C. anseris, виявляється еритропенія, лейкоцитоз, еозинофілія, лімфопенія, зниження вмісту гемоглобіну та зростання кількості псевдоеозинофілів.

Перспективи подальшої роботи в цьому напрямі. Перспективами подальших досліджень $\epsilon$ визначення біохімічних показників сироватки крові гусей, інвазованих гельмінтами роду Capilaria.

7. Мухаметшин И. А. Смешанные инвазии гусей и кур в хозяйствах Предуралья Республики Башкортостан : дис. ... к. б. н. : 03.00 .19 / И. А. Мухаметшин. - Уфа, 2004. - 179 с.

8. Павленко С. В. Моніторинг гельмінтозів свійської птиці в господарствах Дніпропетровської та Запорізької областей і заходи профілактики / С. В. Павленко, І. І. Коваленко, Т. В. Маршалкіна, Г. В. Заікіна // Ветеринарна медицина : міжвід. темат. наук. зб. - Х., 2008. №91. - С. 352-355.

9. Соловьева Л. Н. Гименолепидидозы водоплавающих птиц и меры борьбы с ними в Среднем Поволжье : дис. ... к. вет. н. : 03.00.19, 16.00.03 / Л. Н. Соловьева. - Иваново, 2005. $119 \mathrm{c}$.

10. Цветаева Н. П. Патоморфология основных гельминтозов птиц / Н. П. Цветаева. - М., 1971. $112 \mathrm{c}$.

11. Чебымев Н. В. Гельминтозы: органно-системные процессы в их патогенезе и лечении / Н. В. Чебышев, Ю. К. Богоявленский, Е. А. Гришина. - М. : Медицина, 1998. - 240 с. 